dr hab. Józef Górski, prof. ucz. ${ }^{1}$

\title{
ULATWIONA MIGRACJA ZANIECZYSZCZEŃ DO UŻYTKOWYCH POZIOMÓW WODONOŚNYCH W WYNIKU WAD TECHNICZNYCH STUDNI I OTWORÓW HYDROGEOLOGICZNYCH
}

https://doi.org/10.18778/8220-655-5.05

\begin{abstract}
Streszczenie: W artykule przedstawiono przykłady występowania, w głębokich dobrze izolowanych poziomach wodonośnych, zanieczyszczeń typowych dla wód przypowierzchniowych, w tym w szczególności bakteriologicznych. Udokumentowano, że zjawisko to może być związane z niezamknięciem poziomów przypowierzchniowych w trakcie wiercenia studni, a także brakiem lub niewłaściwym uszczelnieniem głowicy studni. Przedstawiono również w jaki sposób należy wykonać analizy chemiczne i bakteriologiczne w celu udokumentowania wad technicznych studni.
\end{abstract}

Słowa kluczowe: migracja zanieczyszczeń, zanieczyszczenia bakteriologiczne, zamykanie poziomów wodonośnych, wady techniczne studni i otworów hydrogeologicznych.

\section{Wprowadzenie}

Badania jakości wód ze studni ujmujących poziomy wodonośne dobrze chronione nadkładem utworów słabo przepuszczalnych wykazują niekiedy przejawy występowania zanieczyszczeń typowych dla bardzo płytkich, czasami wręcz zaskórnych wód gruntowych. Dotyczy to nawet bardzo głębokich, izolowanych poziomów wodonośnych, do których czas dotarcia zanieczyszczeń konserwatywnych, migrujących poprzez środowisko geologiczne, wynosi setki, a nawet tysiące lat. Przyczyny zanieczyszczenia należy więc szukać w samym obiekcie ujęcia wody, bądź też położonych w jego pobliżu nieczynnych studniach lub otworach wiertniczych. Najczęściej przyczyną jest przenikanie zanieczyszczeń wzdłuż kolumny rur studziennych z niezamkniętych płytkich poziomów wód gruntowych. Czasami również płytkie wody zaskórne mogą przenikać do studzienek stanowiących obudowę studni wierconych i wlewać się bezpośrednio do studni poprzez jej głowicę.

W przypadku starych otworów może także dochodzić do przenikania zanieczyszczeń do wnętrza studni poprzez skorodowane orurowanie. Inną przyczyną zanieczyszczenia może być migracja do studni lub otworu wiertniczego zanieczyszczonych wód opadowych. Zjawisko to, często obserwowane przy studniach kopanych, w przypadku studni wierconych może w szczególności zachodzić przed wykonaniem ich obudów. Zagrożenie dla ujęcia mogą stanowić jednak również położone w jego pobliżu otwory, jeśli nie wykonano prawidłowego zabezpieczenia ich głowic przy powierzchni terenu. Należy podkreślić, że największy problem związany z przenikaniem do studni płytkich wód przypowierzchniowych stanowi możliwość bakteriologicznego zanieczyszczenia ujmowanych wód.

\footnotetext{
${ }^{1}$ Uniwersytet im. Adama Mickiewicza w Poznaniu, Wydział Nauk Geograficznych i Geologicznych, Instytut Geologii, Pracownia Hydrogeologii i Ochrony Wód, ul. Bogumiła Krygowskiego 10, 61-680 Poznań, gorski@ amu.edu.pl, ORCID 0000-0001-8628-4515
} 
Ułatwiona migracja zanieczyszczeń do użytkowych poziomów wodonośnych w wyniku wad technicznych...

\section{Migracja zanieczyszczeń z niezamkniętych poziomów wodonośnych}

Ogólnie wiadomo, że przy wykonywaniu studni i otworów hydrogeologicznych powinna być stosowana zasada zamykania poziomów wodonośnych. Praktyka wykazuje jednak, że zasada ta nie zawsze jest stosowana. Dotyczy to w szczególności braku zamknięcia płytkich, przypowierzchniowych poziomów wodonośnych, których wody są często silnie zanieczyszczone. Wody takie mogą przenikać nawet do głębokich poziomów wodonośnych pomiędzy rurą studzienną a naruszonym w trakcie wiercenia środowiskiem geologicznym. Schemat takiej sytuacji przedstawia ryc. 1 .

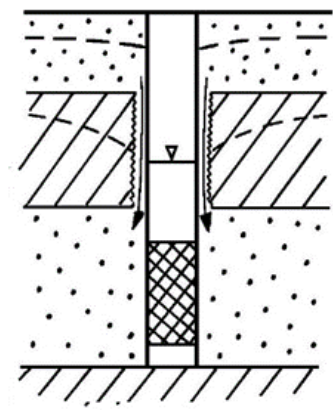

Ryc. 1. Przykład studni z wadą techniczną wynikającą z braku zamknięcia poziomu wodonośnego

Źródło: opracowanie własne

Zjawisko ułatwionej migracji zanieczyszczeń z płytkiego zanieczyszczonego poziomu przypowierzchniowego dobrze ilustruje przykład studni o głębokości $23 \mathrm{~m}$ wykonanej na terenie rolniczym dla Stacji Redukcji Gazu w rejonie Granowa (ryc. 2).

Sygnałem wskazującym na taką możliwość był stwierdzany przez użytkownika ujęcia fakt pojawiania się $\mathrm{w}$ wodzie zanieczyszczenia bakteriologicznego. Nie było to jednak zanieczyszczenie stałe, pojawiało się bowiem tylko w niektórych analizach.

W ciągu 2. lat eksploatacji ujęcia ciągle jednak okresowo pojawiało się zanieczyszczenie bakteriologiczne.

W celu wyjaśnienia przyczyn tego zjawiska wykonane zostały kompleksowe badania, które objęły:

- rozpoznanie stopnia zanieczyszczenia płytkiego poziomu przypowierzchniowego;

- wykonanie badań bakteriologicznych i hydrochemicznych wody ze studni.

Badania poziomu przypowierzchniowego potwierdziły silne zanieczyszczenia $\mathrm{w}$ wyniku oddziaływania ścieków z nieszczelnego systemu kanalizacyjnego (nieszczelne szamba i rurociągi). Zasadniczym celem badań było jednak wyjaśnienie dlaczego zanieczyszczenia bakteriologiczne wykrywane są tylko w niektórych analizach. W celu wyjaśnienia tego problemu pobrane zostały dwie próbki wody do analizy - jedna po kilkunastogodzinnym postoju studni (próbka została pobrana po wypompowaniu wody stagnującej w kolumnie filtracyjnej), druga po długotrwałej (kilkunastogodzinnej) pracy studni.

Wyniki analiz przedstawione na ryc. 2 wskazują, że zanieczyszczenie bakteriologiczne zaznaczyło się wyraźnie tylko w próbce $\mathrm{nr} 1$ - pobranej po długim postoju studni. Przejawem były bakterie grupy Coli, których nie wykryto w próbce 2 . W próbce $\mathrm{nr} 1$ wyższe były również liczby bakterii wyhodowanych $\mathrm{w}$ temperaturze $20^{\circ} \mathrm{C}$ i $37^{\circ} \mathrm{C}$. 


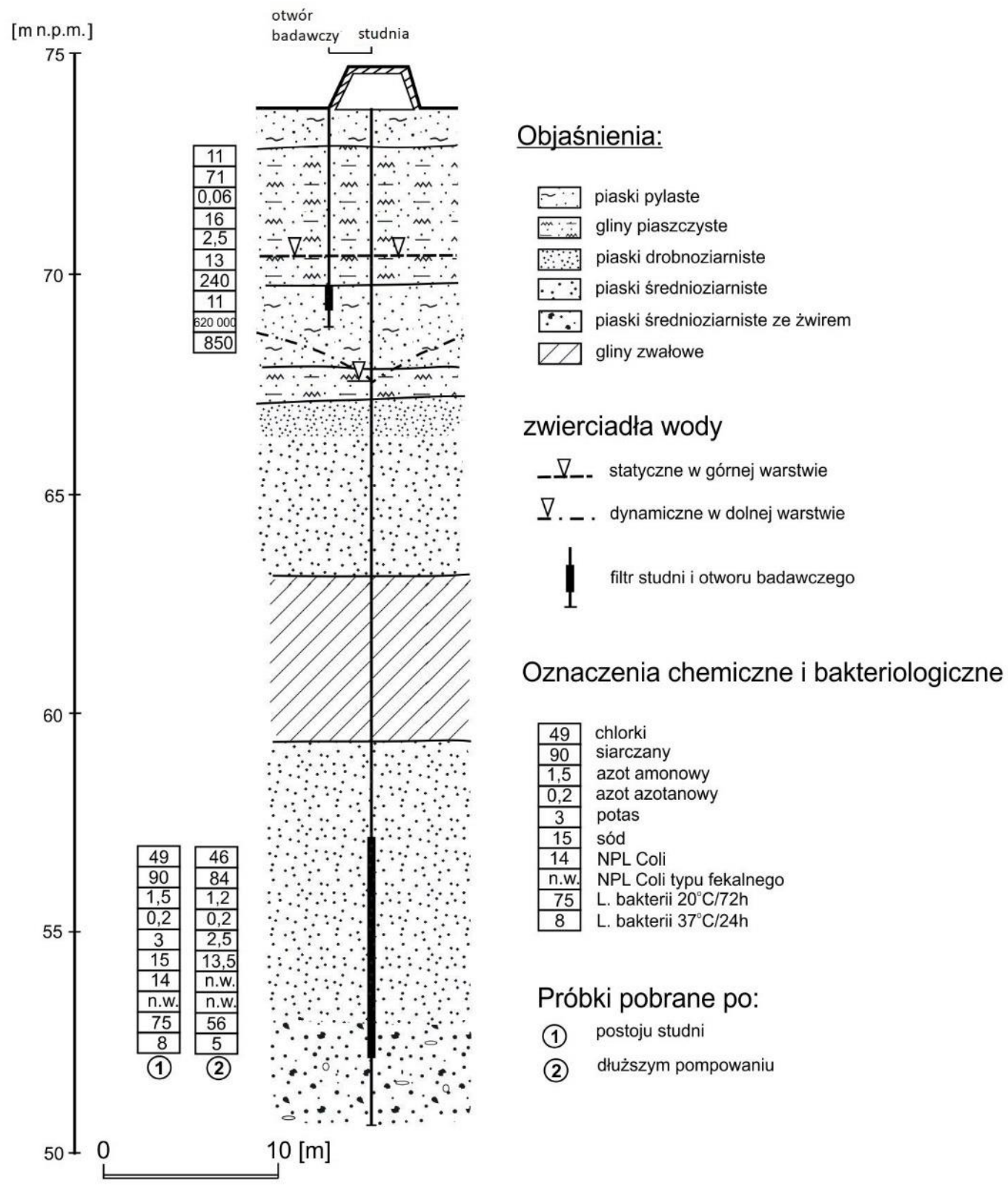

Ryc. 2. Przekrój hydrogeochemiczny ukazujący migrację do studni zanieczyszczeń z płytkiego poziomu przypowierzchniowego

Źródło: opracowanie własne

Ponadto w próbce $\mathrm{nr} 1$ były nieco wyższe stężenia $\mathrm{Cl}, \mathrm{SO}_{4}, \mathrm{NH}_{4}, \mathrm{~K}$ i Na. Powyższe różnice wynikają $\mathrm{z}$ faktu, że w trakcie postoju studni następowało stopniowe gromadzenie się w strefie zafiltrowanej zanieczyszczeń migrujących z poziomów przypowierzchniowych. W warunkach długotrwałej pracy studni dominujący był natomiast dopływ z warstwy wodonośnej, a niewielka ilość wód migrujących z poziomu przypowierzchniowego miała niewielki wpływ na wynik analizy. 
Ułatwiona migracja zanieczyszczeń do użytkowych poziomów wodonośnych w wyniku wad technicznych...

Inny przykład migracji zanieczyszczeń z płytkiego poziomu przypowierzchniowego przedstawiono na ryc. 3 (Kaźmierczak-Wijura 1998).
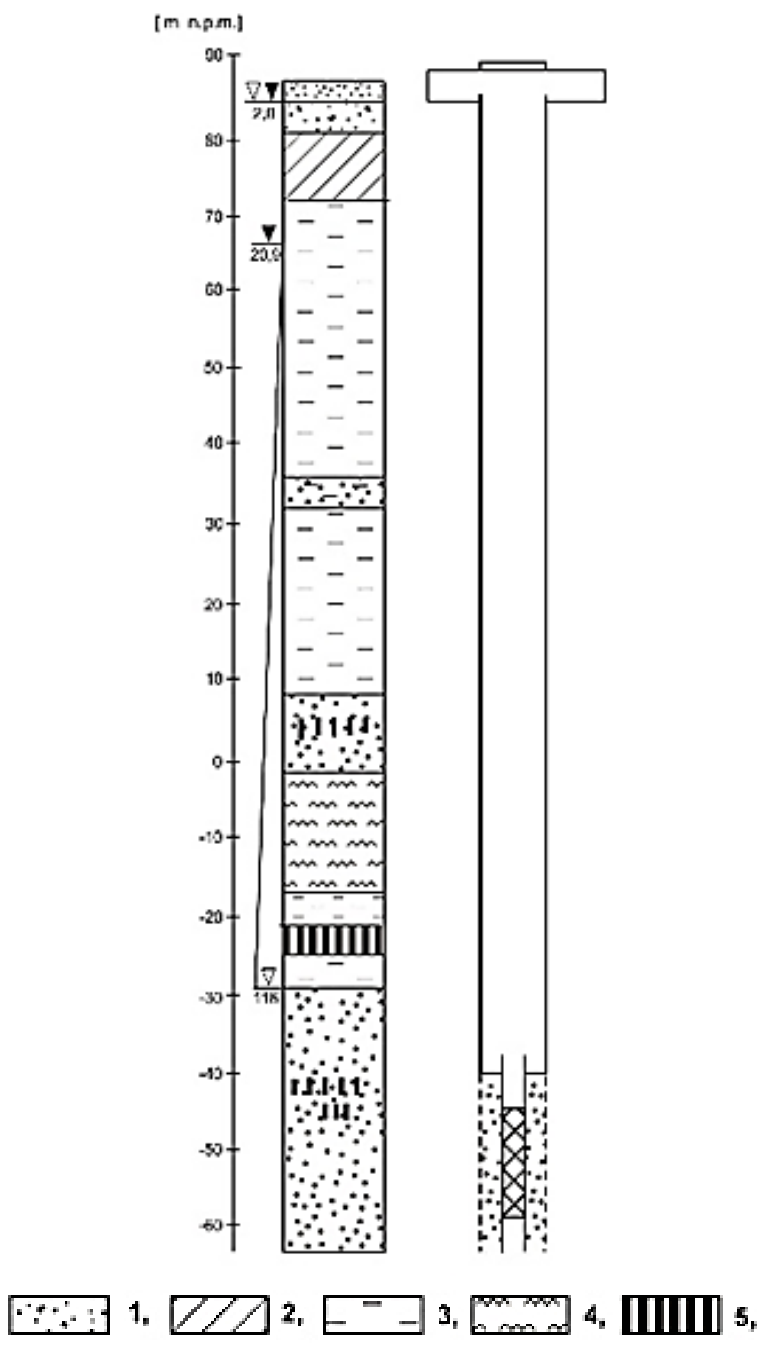

Ryc. 3. Profil studni na terenie Zakładu Reprodukcji Kur w Brodziszewie

Objaśnienia: 1 - piaski, 2 - gliny zwałowe, 3 - iły, 4 - mułki, 5 - węgle brunatne

Źródło: zmodyfikowane za Kaźmierczak-Wijura 1989

Przykład dotyczy studni o głębokości 163 m ujmującej wody poziomu mioceńskiego na terenie Zakładu Reprodukcji Kur w Brodziszewie. W studni tej występuje od powierzchni poziom wodonośny o miąższości kilku metrów, który był poddany oddziaływaniu ścieków z fermy drobiu, które po mechanicznym oczyszczeniu pompowane były na złoża filtracyjne i rozsączane do gruntu.

Ujęta w studni warstwa wodonośna jest bardzo dobrze chroniona serią glin i iłów miopliocenu. Pomimo tego w wodzie pojawiały się zanieczyszczenia bakteriologiczne (tab. 1). 
Tab. 1. Parametry mikrobiologiczne wody ze studni Zakładu Reprodukcji Kur w Bodziszewie

\begin{tabular}{|l|c|c|}
\hline \multicolumn{1}{|c|}{ Parametr } & $\begin{array}{c}\text { Woda stagnująca } \\
\text { w kolumnie studni } \\
\text { (początek czerpania) }\end{array}$ & $\begin{array}{c}\text { Woda z warstwy po } \\
\text { wymianie objętości } \\
\text { przekraczającej } \\
\text { pojemność kolumny } \\
\text { studni }\end{array}$ \\
\hline Wskaźnik Coli w $100 \mathrm{~cm}^{3}$ & 1 & 11 \\
\hline Wskaźnik coli typu fekalnego w $100 \mathrm{~cm}^{3}$ & 0 & 8 \\
\hline Liczba kolonii na agarze w $1 \mathrm{~cm}^{3}-20^{\circ} \mathrm{C}$ po $72 \mathrm{~h}$ & 10 & 1700 \\
\hline Liczba kolonii na agarze $\mathrm{w} 1 \mathrm{~cm}^{3}-37^{\circ} \mathrm{C}$ po $24 \mathrm{~h}$ & 2 & 260 \\
\hline
\end{tabular}

Źródło: zmodyfikowane za Kaźmierczak-Wijura 1989.

Zaznaczyły się również zmiany parametrów chemicznych w stosunku do danych z okresu budowy studni (tab. 2). Przejawem tego są stężenia azotanów i siarczanów. Powyższe zanieczyszczenia są niewątpliwie związane z migracją zanieczyszczeń z poziomu przypowierzchniowego wzdłuż rury nadfiltrowej studni.

Tab. 2. Parametry fizykochemiczne wody ze studni Zakładu Reprodukcji Kur w Bodziszewie

\begin{tabular}{|l|c|c|}
\hline \multicolumn{1}{|c|}{ Skladnik } & $\begin{array}{c}\text { Okres } \\
\text { budowy }\end{array}$ & $\begin{array}{c}\text { Podczas } \\
\text { eksploatacji }\end{array}$ \\
\hline Azot azotanowy $\left[\mathrm{mgN} / \mathrm{dm}^{3}\right]$ & 0,1 & 5,00 \\
\hline Azot amoniakalny $\left[\mathrm{mgN} / \mathrm{dm}^{3}\right]$ & 0,8 & 0,28 \\
\hline Siarczany $\left[\mathrm{mg} / \mathrm{dm}^{3}\right]$ & 13,9 & 72,00 \\
\hline Chlorki $\left[\mathrm{mg} / \mathrm{dm}^{3}\right]$ & 23,0 & 20,00 \\
\hline Żelazo $\left[\mathrm{mg} / \mathrm{dm}^{3}\right]$ & 0,6 & 2,00 \\
\hline
\end{tabular}

Źródło: zmodyfikowane za Kaźmierczak-Wijura 1989.

Należy dodać, że zjawisko ułatwionej migracji zanieczyszczeń z płytkich przypowierzchniowych poziomów wodonośnych do głębokich studni ujmujących poziom wodonośny miocenu zostało również zidentyfikowane w kilku innych studniach na terenie środkowej Wielkopolski (Górski 1989).

\section{Migracja zanieczyszczeń poprzez nieuszczelnioną głowicę studni lub otworu hydrogeologicznego}

Problem ten obserwuje się w szczególności w przypadku studni kopanych. Studnie takie bardzo często nie posiadają odpowiedniego uszczelnienia wokół cembrowiny. Migracja zanieczyszczeń zachodzi w szczególności jeśli teren przy studni jest obniżony, a studnia jest zbudowana $\mathrm{z}$ betonowych odcinków cembrowiny (ryc. 4). 
Ułatwiona migracja zanieczyszczeń do użytkowych poziomów wodonośnych w wyniku wad technicznych...

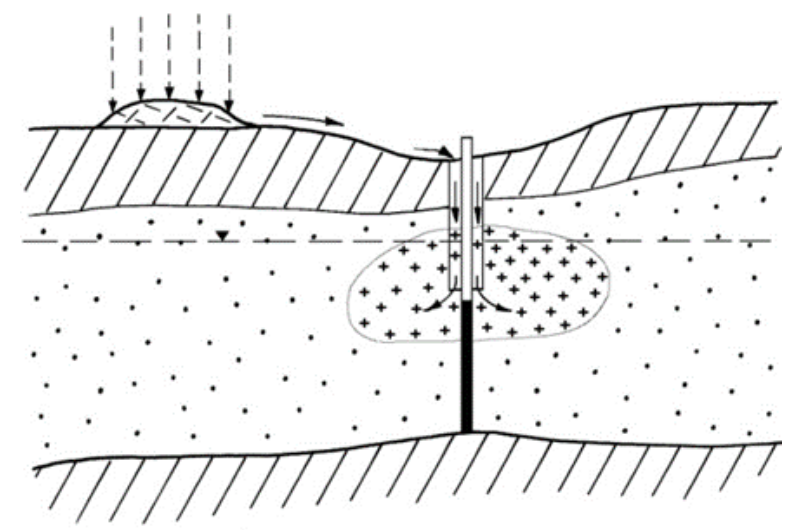

Ryc. 4. Schemat migracji zanieczyszczeń do studni bez uszczelnienia głowicy przy powierzchni terenu

Źródło: zmodyfikowane za Kleczkowski (red.) 1984

Sytuacja taka sprzyja migracji do studni nie tylko zanieczyszczonych wód powierzchniowych, ale również płytkich wód zaskórnych. Dodatkowym czynnikiem może być brak zamknięcia studni, do której mogą przedostawać się różnego typu zanieczyszczenia drogą eoliczną.

Szczególne warunki migracji zanieczyszczeń mogą występować w przypadku studni kopano-wierconych, czyli w studniach kopanych, w których dnie wykonano studnię wierconą bez odizolowania od płytkiego poziomu ujmowanego w studni kopanej.

Sytuację taką dobrze ilustruje przykład dwóch studni kopanych, pogłębionych poprzez wykonanie wierceń w ich dnie (Kazimierczak-Wijura 1998). Studnie kopane w rejonie Głuszyny i Rogalina ujmowały pierwszy od powierzchni poziom wodonośny zanieczyszczony w wyniku oddziaływania rolnictwa, w tym ścieków przemysły ziemniaczanego. Obie studnie zostały pogłębione poprzez wiercenie do poziomu wielkopolskiej doliny kopalnej chronionej od płytkiej warstwy ponad 20-to metrową warstwą glin. W jednej z tych studni pozostał słup wody pierwszego poziomu wód gruntowych, w drugiej zaś zasypano studnie gliną pochodzącą z wiercenia do wysokości słupa wody tworząc rodzaj zamknięcia pierwszego poziomu wodonośnego.

Badania wody ze studni, gdzie pozostawiony został słup wody pierwszego poziomu wykazały bardzo wyraźne zanieczyszczenie azotem azotanowym - 25 mg/l, siarczanami - 160 mg/l i chlorkami - $80 \mathrm{mg} / \mathrm{l}$. W drugiej studni, gdzie wykonano uszczelnienie z gliny, stężenia wcześniej wymienionych parametrów były znacznie niższe $\left(\mathrm{NNO}_{3}-0,7 \mathrm{mg} / \mathrm{l}, \mathrm{SO}_{4}-55 \mathrm{mg} / \mathrm{l}\right.$, $\mathrm{Cl}-25 \mathrm{mg} / \mathrm{l})$ i odzwierciedlały naturalny stan jakości wody w poziomie wielkopolskiej doliny kopalnej.

Dane te pokazują dobitnie, że poprzez odwiercenie otworu w dnie studni stworzona została droga migracji zanieczyszczonych wód górnej warstwy wzdłuż rury nadfiltrowej do poziomu wielkopolskiej doliny kopalnej.

Migracja zanieczyszczeń z powierzchni terenu lub z wód zaskórnych może następować również w przypadku studni i otworów wierconych, dla których nie wykonano właściwego zabezpieczenia ich głowic. Dobitny przykład ilustrujący taką sytuację zaobserwowano przy pompowaniu wody ze świeżo wykonanego otworu studziennego o głębokości ok. $40 \mathrm{~m}$. 
W trakcie pompowania nadeszła gwałtowna burza i trzeba było je przerwać. Po burzy wznowiono pompowanie, ale okazało się, że pompowana jest żółta woda powstała w wyniku rozmycia glin przy powierzchni terenu. Wody te, z powierzchni terenu, natychmiast spłynęły wzdłuż rury nadfiltrowej do filtra na głębokości $20 \mathrm{~m}$. Spływ ułatwił fakt, że teren przy wylocie rury nadfiltrowej był obniżony i nieuporządkowany po wierceniu studni. Przypadek ten pokazuje, że uszczelnienie głowicy studni czy otworu wiertniczego powinno być wykonane chociażby prowizorycznie zaraz po zakończeniu wiercenia.

Migracja zanieczyszczeń z płytkich poziomów przypowierzchniowych może zachodzić również w przypadku możliwości pojawienia się takich wód w obudowach studni wierconych i bezpośredniego wlewania się tych wód przez głowicę studni. Sytuację taką obrazuje przykład studni w miejscowości Gonne Małe.

W wodzie z wodociągu wiejskiego w tej miejscowości stwierdzono zanieczyszczenia bakteriologiczne wody ujmowanej ze studni głębinowej. Przejawem zanieczyszczenia była ogólna liczba bakterii wyhodowanych w temperaturze $22^{\circ} \mathrm{C} \mathrm{w} 1 \mathrm{ml}$ po 72 godzinach. Wartość tego wskaźnika w okresie od 4.04.2003 r. do 17.06.2003 r. utrzymywała się powyżej poziomu dopuszczalnego wg przepisów sanitarnych i wynosiła najczęściej $>300$ bakterii w $1 \mathrm{ml}$ wody. Pozostałe badane parametry nie wykazywały zanieczyszczenia. Ogólna liczba bakterii wyhodowanych w temperaturze $37^{\circ} \mathrm{C}$ po 24 godzinach wynosiła 1 lub $<1 \mathrm{w} 1 \mathrm{ml}$. Nie wykrywano natomiast bakterii grupy coli i grupy coli typu kałowego oraz paciorkowców kałowych. Brak było również wyraźnych oznak zanieczyszczenia chemicznego ujmowanej wody.

Rozpatrując przyczynę zanieczyszczenia władze miejscowe skierowały podejrzenie na firmę prowadzącą fermę hodowli świń, stosującą gnojowicowanie pól otaczających ujęcie wody. Analiza warunków hydrogeologicznych w rejonie ujęcia, wyniki analiz chemicznych oraz charakter zanieczyszczenia bakteriologicznego wody nie wskazywały jednak na taką przyczynę zanieczyszczenia. Woda ujmowana była bowiem z poziomu wodonośnego izolowanego od powierzchni warstwą glin zwałowych o miąższości $30 \mathrm{~m}$. Dodatkowym czynnikiem utrudniającym ewentualną migrację zanieczyszczeń bakteriologicznych był fakt zalegania statycznego zwierciadła wody na głębokości $25 \mathrm{~m}$. Jedynie przy powierzchni występowała ok. 3-metrowa warstwa piasków gliniastych, w której mogły się zbierać wody zaskórne.

Wyraźnego zanieczyszczenia antropogenicznego wody ze studni nie wykazała również analiza składu chemicznego wykonana w okresie występowania zanieczyszczenia bakteriologicznego. Stwierdzono skład typowy dla naturalnego środowiska hydrochemicznego ujętego poziomu wodonośnego, zbliżonego do stanu jaki stwierdzono w trakcie budowy studni w roku 1976.

Za pewien przejaw zanieczyszczenia można było uznać jedynie niewielki wzrost azotu azotanowego, którego stężenie w roku 1976 wynosiło $0,08 \mathrm{mg} / \mathrm{l}$ i wzrosło do $0,3 \mathrm{mg} / \mathrm{l}$. Nie thumaczyło to jednak pojawienia się zanieczyszczenia bakteriologicznego, tym bardziej, że miało ono charakter okresowy. 
Ułatwiona migracja zanieczyszczeń do użytkowych poziomów wodonośnych w wyniku wad technicznych...

Przyczynę zanieczyszczenia bakteriologicznego udało się ustalić dopiero na podstawie szczegółowej wizji ujęcia i otaczającego go terenu oraz wywiadu z okoliczną ludnością. Okazało się mianowicie, że w pobliżu ujęcia, w odległości 100 m, znajdował się niewielki staw, przez który przepływał mały strumyk.

Z wywiadu wynikało, że odpływ z tego stawu został okresowo zablokowany przez bawiące się dzieci. Spowodowało to podwyższenie się zwierciadła płytkich wód zaskórnych, które zebrały się w studzience obudowy studni i wody te poprzez głowicę rury nadfiltrowej wlały się bezpośrednio do studni.

\section{Migracja zanieczyszczeń pochodzenia geogenicznego do poziomów użytkowych}

W użytkowych poziomach wodonośnych możemy niekiedy obserwować pojawienie się wód o podwyższonym zasoleniu lub zabarwieniu. Pojawienie się takich wód, typowych dla głębszych poziomów wodonośnych może być efektem ich ascenzji do poziomów użytkowych. Warunki do ascenzji mogą być spowodowane naturalnymi czynnikami bądź też wynikają z migracji poprzez studnie lub otwory hydrogeologiczne. Warunki do naturalnej ascenzji wynikają z wytworzenia się lokalnych kontaktów pomiędzy poziomami wodonośnymi w wyniku erozji bądź też zaznaczają się wzdłuż aktywnych hydraulicznie uskoków tektonicznych. Przypadki ascenzji wód o podwyższonym zasoleniu do poziomów użytkowych w czwartorzędzie zaznaczają się w szczególności w dolinach rzecznych i znane są w dolinie Warty w rejonie miejscowości Pyzdry oraz Słonawy koło Obornik. Lokalnie stwierdzono również zasolenie poziomu WDK w rejonie Stęszewa w strefie kontaktu piaszczystych osadów czwartorzędu i miocenu, a także w rejonie Śremu, gdzie ascenzję ułatwiają uskoki tektoniczne (Górski 1989). Przypadek naturalnej ascenzji wód silnie zabarwionych z poziomu mioceńskiego do czwartorzędowego stwierdzony został w dolinie odcinka ujściowego rzeki Bogdanki w Poznaniu.

Ascenzja wód zasolonych i/lub zabarwionych może zachodzić jednak również przez studnie i otwory hydrogeologiczne. Powodem może być brak zamknięcia ujętego poziomu od poziomu płytszego bądź też korozja konstrukcji otworu, który nie został zlikwidowany, co umożliwia przepływ z kolumny filtracyjnej. Zjawisko takie obserwowano m.in. w dolinie rzeki Słupi na terenie Słupska.

Ascenzję wód silnie zabarwionych z poziomu mioceńskiego do poziomu wielkopolskiej doliny kopalnej stwierdzono w rejonie miejscowości Joanka pomiędzy Dopiewem a Stęszewem. Ascenzja następuje tu poprzez starą studnię ujmującą zabarwione wody poziomu mioceńskiego. Problem został szczegółowo przedstawiony w publikacji Dragona i in. (2007).

\section{Wnioski}

1. W niektórych studniach ujmujących wody głębokich, dobrze izolowanych poziomów wodonośnych, mogą występować zanieczyszczenia typowe dla płytkich wód przypowierzchniowych, w tym w szczególności bakteriologiczne. Przyczyną występowania takich zanieczyszczeń może być brak zamknięcia przypowierzchniowych poziomów wodonośnych w trakcie wiercenia studni. 
2. W celu stwierdzenia czy przyczyną zanieczyszczenia jest brak zamknięcia przypowierzchniowego poziomu wodonośnego należy wykonać analizę wody ze studni po długotrwałej eksploatacji (rzędu kilkunastu godzin) i porównać z analizą wody wykonana po kilkugodzinnym postoju studni.

3. Przyczyną zanieczyszczenia wodami powierzchniowymi i zaskórnymi może być brak właściwego uszczelnienia głowicy studni. Dotyczy to najczęściej studni kopanych. Istnieje również możliwość wlewania się wód zaskórnych do obudowy studni wierconych w przypadku niewłaściwego posadowienia obudowy oraz piętrzenia wód gruntowych w sąsiedztwie studni.

4. Przykład zaprezentowany w artykule wskazuje również na możliwość wlewania się zanieczyszczonych wód powierzchniowych do studni zaraz po zakończeniu wiercenia, przed wykonaniem obudowy. Wskazuje to na konieczność wykonywania nawet prowizorycznego uszczelnienia głowicy otworu przed realizacją właściwej obudowy.

5. Problemy właściwego zamykania poziomów wodonośnych i w szczególności uszczelniania głowic są również bardzo istotne przy wykonaniu otworów badawczych służących do monitoringu wód podziemnych.

\section{Bibliografia}

Dragon K., Górski J., Marciniak M., Kasztelan D., 2007, Geneza i warunki migracji intensywnie zabarwionych wód w poziomie wielkopolskiej doliny kopalnej, Geologos Monographiae 4, UAM, Poznań: 59.

Górski J., 1989, Główne problemy chemizmu wód podziemnych utworów kenozoiku środkowej Wielkopolski, Zesz. Nauk., AGH Kraków, z. 45, zał. 23: 117.

Kaźmierczak-Wijura Z., 1998, Antropogeniczne zanieczyszczenia wód podziemnych w wyniku wad technicznych otworów hydrogeologicznych. Zaopatrzenie $w$ wodę miast $i$ wsi, PZTS Poznań, 1: 125-132.

Kleczkowski A.S. (red.), 1984, Ochrona wód podziemnych, Wyd. Geol., Warszawa: 328. 